\title{
EFFECT OF CROSSWORD PUZZLE TEACHING STRATEGY TOWARDS STUDENTS' VOCABULARY MASTERY
}

\author{
Vivin Sunarko ${ }^{1}$, Priska Novita Silalahi ${ }^{2}$, Nani Haro ${ }^{3}$, Sri Ninta Tarigan ${ }^{4}$ \\ 1,2,3,4 English Education, Faculty of Teacher Training and Education \\ Universitas Prima Indonesia \\ e-mail: vivinxi88@gmail.com
}

Received: 22 November 2019

Accepted: 16 December 2019

\begin{abstract}
This research is to find out that crossword puzzle teaching strategy gives a significant effect towards students' vocabulary mastery at SMA Amir Hamzah Medan. The crossword puzzle is a kind of word game, which can improve the learners to enrich their vocabulary knowledge. The research design used is pre-experimental design formed as one group pretestposttest design using quantitative approach. The data collecting method is test. The research data are analyzed by applying paired samples t-test formula through SPSS 23 and the result of the research shows that the value of the t-count is 51,700 , while the t-table with the significance level of $5 \%$ and $D f$ of 12 is 2,179 . The t-count is higher than the t-table $(51,700>2,179)$. This means that the null hypothesis $(\mathrm{HO})$ is rejected while the alternative hypothesis $(\mathrm{Ha})$ is accepted. In conclusion, there is a significant effect towards students' vocabulary mastery before and after having taught by the utilization of crossword puzzle teaching strategy at SMA Amir Hamzah Medan.
\end{abstract}

Keywords: Crossword Puzzle, Teaching Strategy, Vocabulary Mastery

\section{Introduction}

Nowadays, English has become one of the medium to communicate among members of society and has been used by people in many parts of the world. Therefore, English is known as an international language. Imam (2018) states that English has become a part of education curriculum since 1967 in Indonesia. English is taught from primary level up to university level. One basic element in English language is vocabulary.

As a teacher, it is a common knowledge that vocabulary is one of the important skills to be taught at schools. People would not be able to express their opinion, ideas, and thoughts in English without knowing vocabulary. Cahyono and Kusumaningrum (2011) states that vocabulary is one of the language components needed to be mastered when students are learning English. Without having adequate vocabulary, the students would have some difficulties to know the meaning of what they listen and read as well as to express their thoughts in order to communicate with people. Thus, students need to learn vocabulary to develop their language skills. Many students still lack in vocabulary resulting in low English scores because of inability to listen, read, speak and write efficiently.

\section{Literature Review}

Allen (1983) states that teaching vocabulary will be deemed as a meaningful avenue for teachers if they can conduct and combine a wide ranging of available technique of teaching. 
Effect of Crossword Puzzle Teaching Strategy towards Students' Vocabulary Mastery, Vivin Sunarko, Priska Novita Silalahi, Nani Haro, Sri Ninta Tarigan

This is undertaken as it is hoped to provide an innovative and insightful teaching technique that will be experienced by students as more enjoyable, interesting and motivating so that the boredom and dull atmosphere in the classroom teaching can be eliminated.

Based on that, the researchers have found an enjoyable, interesting, motivating and creative strategy to solve the problems often faced by students' in regards to the mastery in vocabulary. This teaching model is known as crossword puzzle teaching strategy. Hornby (1987) states that crossword puzzle is a puzzle or a word play where the words have to be written related to numbered clues vertically or horizontally in blank spaces in the squares formed. Karim and Hasbullah (1986) who find crossword puzzle as one of interesting techniques in teaching language also support this.

By applying crossword puzzle teaching strategy in teaching vocabulary, students will be entertained and stimulated to think of the appropriate words to fill the blank spaces. It makes the learning process more enjoyable, entertaining, interesting, yet challenging.

There have been several relevant studies done related to this research. One of the researches was conducted by Ratnawati (2013). The research design that she used was Preexperimental research using Non Equivalent Group Post-test Only research design that focused on the significant effect of using crossword puzzle in students' vocabulary achievement. She conducted her research at SMPN 5 Jember and finally found that there was a significant effect in using crossword puzzle towards vocabulary achievement of the students in SMP Negri 5 Jember.

Another research was conducted by Pratiwi (2016). The research data used were qualitative and quantitative data. The qualitative data's form were vignettes and interview transcripts while the quantitative data's form were the scores of pre-test and post- test. Her research was focused in improving the vocabulary mastery of grade VIII C students through contextual crossword puzzle at SMPN 7 Yogyakarta. The result of the research showed that some improvements happened on students' vocabulary mastery by using contextual crossword puzzle.

Based on the previous relevant studies above, since most research had been conducted at junior high school level and none has ever been conducted at SMA Amir Hamzah Medan, the researchers decided to conduct a research entitled "The Effect of Crossword Puzzle Teaching Strategy Towards Student's Vocabulary Mastery at SMA Amir Hamzah Medan". The research question was formulated as "Is there any significant effect in students' vocabulary mastery before and after being taught by using crossword puzzle teaching strategy at SMA Amir Hamzah Medan?". To answer the research question, hypothesis was needed. According to Prasetyo and Jannah (2014) hypothesis is a temporary answer of a research question. The researchers formulated the hypothesis as follow:

1. Null Hypothesis (HO): "There is no significant effect in students' vocabulary mastery before and after being taught by using crossword puzzle teaching strategy in SMA Amir Hamzah Medan."

Alternative Hypothesis ( $\mathrm{Ha})$ : "There is significant effect in students' vocabulary mastery before and after being taught by using crossword puzzle teaching strategy in SMA Amir Hamzah Medan."

\section{Research Method}

The research design used in this research was pre-experimental design formed as one group pretest-posttest design using quantitative approach. There was only one group in this research because the researcher wanted to see the effect of Crossword Puzzle teaching 
strategy towards students' vocabulary mastery by comparing the scores of both pre- test and post-test. There were two variables in this research; they were independent variable and dependent variable. Crossword Puzzle was the independent variable while Vocabulary Mastery was the dependent variable. The research design can be seen in the following table:

Table 2.1 The Test Illustration of 1 Group Pre-Test and Post-Test Design

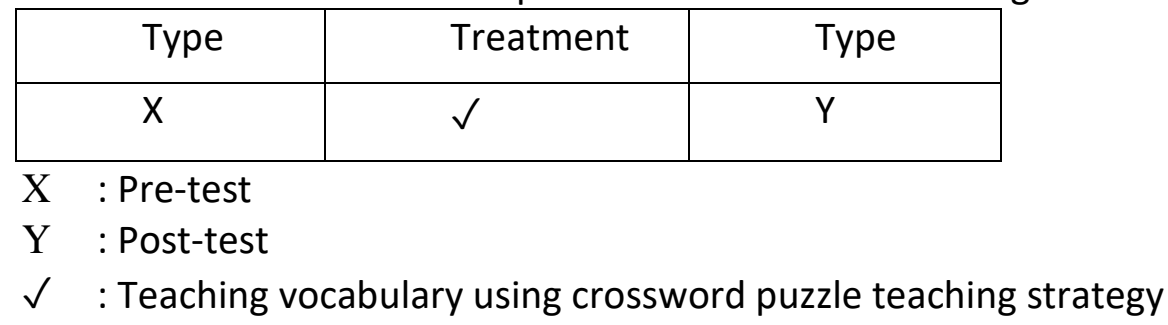

The research was conducted at SMA Amir Hamzah Medan during the academic year of $2019 / 2020$. The researcher decided to select this location because the same research has never been piloted in this school. The population for this research was the students of SMA Amir Hamzah Medan. There were 5 classes; X MIA, XI MIA, XI IIS, XII MIA, and XII IIS. In order to decide the sample, the researcher used simple random sampling technique. Sugiyono (2015: 120) states that simple random sampling is called "simple" because the sampling of the members of the population is done randomly without paying attention to the strata that exists in that population. It was found that the sample for this research was the first grade students of SMA Amir Hamzah Medan. There was only one class; X MIA, consisted of 13 students.

The data collection method for this research was test. The test was divided into two; pre-test and post-test. The researcher did pre-test to find out the mean scores of students' vocabulary mastery. After the treatment had been done, the post-test was conducted. The aim was to find out whether there was any difference between the mean scores of both the pre-test and the post-test. By looking at the difference, the researchers could conclude whether there was any effect of the crossword puzzle teaching strategy towards the students' vocabulary mastery in X MIA.

The test given to the sample was vocabulary test consisting of 20 questions in the form of vocabulary mastery test. The allocated time for the test was 40 minutes. The students answered the test individually. The researcher made sure that the test was valid by testing the validity using SPSS 23.

Table 2.1 Output of Validity Test

Correlations

\begin{tabular}{|c|c|c|c|c|}
\hline & & Pre_Test & Post_Test & Total_Score \\
\hline \multirow[t]{3}{*}{ Pre_Test } & Pearson Correlation & 1 &, $950^{\pi x}$ & $991^{n \pi}$ \\
\hline & Sig. (2-tailed) & &, 000 &, 000 \\
\hline & $N$ & 13 & 13 & 13 \\
\hline \multirow[t]{3}{*}{ Post_Test } & Pearson Correlation & $950^{\mathrm{xx}}$ & 1 & $983^{\mathrm{nx}}$ \\
\hline & Sig. (2-tailed) &, 000 & &, 000 \\
\hline & $N$ & 13 & 13 & 13 \\
\hline \multirow[t]{3}{*}{ Total_Score } & Pearson Correlation &, $991^{\star x}$ &, $983^{\text {kn }}$ & 1 \\
\hline & Sig. (2-tailed) &, 000 &, 000 & \\
\hline & $\mathrm{N}$ & 13 & 13 & 13 \\
\hline
\end{tabular}

The output showed that the computation of $r$-count was 0,991 and 0,983 which was bigger than $r$-table 0,553 in the significance of $5 \%$ with $N=13$. Therefore, the test was considered valid.

Apart from being valid, the test should also be reliable. According to Sugiyono (2015:175) reliability is used to measure something repeatedly and will produce the same 
Effect of Crossword Puzzle Teaching Strategy towards Students' Vocabulary Mastery, Vivin Sunarko, Priska Novita Silalahi, Nani Haro, Sri Ninta Tarigan

result consistently. It focuses on how consistent we measure whatever we measure. In order to test reliability, SPSS 23 was used. The output can be seen as follows.

Table 2.2 Output of Reliability Test

Reliability Statistics

\begin{tabular}{|r|r|}
\hline $\begin{array}{c}\text { Cronbach's } \\
\text { Alpha }\end{array}$ & N of Items \\
\hline, 949 & 2 \\
\hline
\end{tabular}

The output showed that the computation of Cronbach's Alpha of the test was 0,949 which was bigger than $r$ table that was 0,553 in the significance of $5 \%$ with $\mathrm{N}=13$. Therefore, it could be concluded that the test was reliable. Because the test turned out to be valid and reliable, the test was used to collect the research data. The procedure of collecting data can be seen below:

1. Pre-Test

The aim was to find the mean scores of students' vocabulary mastery.

2. Treatment

The students were taught by using Crossword Puzzle teaching strategy.

Treatment was given for several meetings. The teaching procedure can be seen in the following table:

Table 2.3 The Teaching Procedure

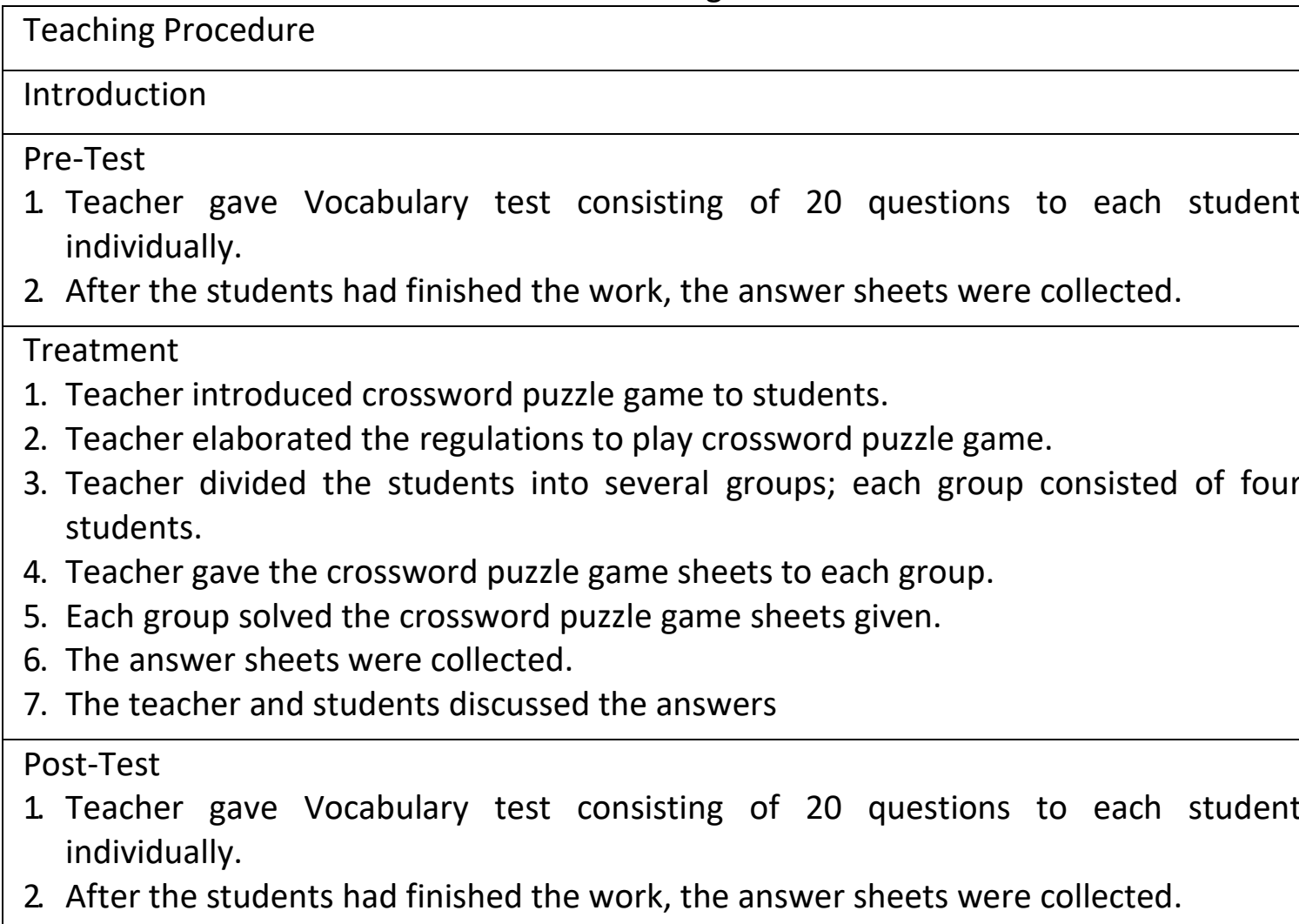

\section{Post-Test}

After the treatment had been done, post-test was conducted to find whether there was any difference between the mean scores of both the pre-test and the post- test. After the researchers got the data, the data were analyzed by using 3 tests: 
1. Normality Test

Normality Test was needed to find whether the data was normally distributed or not. The researchers used SPSS 23 to test normality.

Table 2.4 Output of Normality Test

\begin{tabular}{|l|r|r|r|r|r|r|}
\multicolumn{1}{|c|}{ Tests of Normality } \\
\hline & \multicolumn{2}{|c|}{ Kolmogorov-Smirnov ${ }^{\text {a }}$} & \multicolumn{3}{c|}{ Shapiro-Wilk } \\
\cline { 2 - 7 } & Statistic & \multicolumn{1}{c|}{ df } & \multicolumn{1}{c|}{ Sig. } & Statistic & \multicolumn{1}{c|}{ df } & \multicolumn{1}{c|}{ Sig. } \\
\hline Pre_test &, 178 & 13 &, $200^{*}$ &, 929 & 13 &, 334 \\
Post_test &, 214 & 13 &, 107 &, 894 & 13 &, 110 \\
\hline
\end{tabular}

*. This is a lower bound of the true significance.

a. Lilliefors Significance Correction

The output used was Shapiro-Wilk because the data were less than 50. It was shown that the significance was 0,334 and 0,110 which was higher than 0,05 . This means that both of the data were normally distributed.

2. Hypothesis Test

To test the hypothesis, the data taken from pre-test and post-test were analyzed using T-test through SPSS 23 to find out whether $\mathrm{Ha}$ or $\mathrm{HO}$ could be accepted where the research hypothesis was formulated as follows:

a. Null Hypothesis ( $\mathrm{HO})$ : "There is no significant effect in students' vocabulary mastery before and after being taught by using crossword puzzle teaching strategy in SMA Amir Hamzah Medan."

b. Alternative hypothesis ( $\mathrm{Ha}$ ): "There is significant effect in students' vocabulary mastery before and after being taught by using crossword puzzle teaching strategy in SMA Amir Hamzah Medan."

\section{Results and Discussion}

The pre-test was conducted for the sample on 12th August 2019 and post-test was conducted on 19th August 2019 after the treatment had been given to the students. The scores of both tests were used as the research data. The findings of this research consisted of the data description and the hypothesis test.

To describe the data, the researchers used a score's criteria to decide whether the scores of both tests were considered good or bad. The score's criteria can be seen as follows:

Table 3.1 Score's Criteria

\begin{tabular}{|l|l|l|}
\hline No. & Mean Score & Criteria \\
\hline & $80-100$ & Excellent \\
\hline & $70-79$ & Good \\
\hline & $60-69$ & Average \\
\hline & $50-59$ & Poor \\
\hline & $0-49$ & Low \\
\hline
\end{tabular}

SPSS 23 was used to find out the mean scores. The output can be seen as follows: 
Effect of Crossword Puzzle Teaching Strategy towards Students' Vocabulary Mastery, Vivin Sunarko, Priska Novita Silalahi, Nani Haro, Sri Ninta Tarigan

Table 3.2 Output of Descriptive Statistics

Descriptives

\begin{tabular}{|c|c|c|c|c|}
\hline & & & Statistic & Std. Error \\
\hline \multirow[t]{13}{*}{ Pre_test } & Mean & & 55,77 & 1,776 \\
\hline & \multirow{2}{*}{$\begin{array}{l}95 \% \text { Confidence Interval } \\
\text { for Mean }\end{array}$} & Lower Bound & 51,90 & \\
\hline & & Upper Bound & 59,64 & \\
\hline & \multicolumn{2}{|l|}{$5 \%$ Trimmed Mean } & 55,58 & \\
\hline & \multicolumn{2}{|l|}{ Median } & 55,00 & \\
\hline & \multicolumn{2}{|l|}{ Variance } & 41,026 & \\
\hline & \multicolumn{2}{|l|}{ Std. Deviation } & 6,405 & \\
\hline & \multicolumn{2}{|l|}{ Minimum } & 45 & \\
\hline & \multicolumn{2}{|l|}{ Maximum } & 70 & \\
\hline & \multicolumn{2}{|l|}{ Range } & 25 & \\
\hline & \multicolumn{2}{|l|}{ Interquartile Range } & 10 & \\
\hline & \multicolumn{2}{|l|}{ Skewness } &, 509 &, 616 \\
\hline & \multicolumn{2}{|l|}{ Kurtosis } & 912 & 1,191 \\
\hline \multirow[t]{13}{*}{ Post_test } & \multicolumn{2}{|l|}{ Mean } & 91,15 & 1,285 \\
\hline & \multirow{2}{*}{$\begin{array}{l}95 \% \text { Confidence Interval } \\
\text { for Mean }\end{array}$} & Lower Bound & 88,35 & \\
\hline & & Upper Bound & 93,95 & \\
\hline & \multicolumn{2}{|l|}{$5 \%$ Trimmed Mean } & 91,00 & \\
\hline & \multicolumn{2}{|l|}{ Median } & 90,00 & \\
\hline & \multicolumn{2}{|l|}{ Variance } & 21,474 & \\
\hline & \multirow{2}{*}{\multicolumn{2}{|c|}{$\begin{array}{l}\text { Std. Deviation } \\
\text { Minimum }\end{array}$}} & 4,634 & \\
\hline & & & 85 & \\
\hline & \multirow{2}{*}{\multicolumn{2}{|c|}{$\begin{array}{l}\text { Maximum } \\
\text { Range }\end{array}$}} & 100 & \\
\hline & & & 15 & \\
\hline & \multicolumn{2}{|l|}{ Interquartile Range } & 8 & \\
\hline & \multicolumn{2}{|l|}{ Skewness } & 211 &, 616 \\
\hline & \multicolumn{2}{|l|}{ Kurtosis } &,- 546 & 1,191 \\
\hline
\end{tabular}

Based on the output, the pre-test's mean score which was 55,77 was considered poor while the post-test's mean score which was 91,15 was considered excellent. The scores improved. It proved that there was a significance difference of the students' scores between the pre-test and the post-test.

The aim of the research was to find whether crossword puzzle teaching strategy has an effect towards students' vocabulary mastery. Therefore, the researchers did a T-Test through SPSS 23 using Paired-Samples T-test formula to analyze the research data to test the hypothesis to find out whether $\mathrm{Ha}$ or $\mathrm{HO}$ that could be accepted

Table 3.3 Output of Paired Samples T-Test

Paired Samples Test

\begin{tabular}{|c|c|c|c|c|c|c|c|c|}
\hline & \multicolumn{5}{|c|}{ Paired Differences } & \multirow[b]{3}{*}{$t$} & \multirow[b]{3}{*}{ df } & \multirow[b]{3}{*}{ Sig. (2-tailed) } \\
\hline & \multirow[b]{2}{*}{ Mean } & \multirow[b]{2}{*}{ Std. Deviation } & \multirow{2}{*}{$\begin{array}{l}\text { Std. Error } \\
\text { Mean }\end{array}$} & \multicolumn{2}{|c|}{$\begin{array}{l}\text { 95\% Confidence Interval of the } \\
\text { Difference }\end{array}$} & & & \\
\hline & & & & Lower & Upper & & & \\
\hline Pre_test-Post_test & $-35,385$ & 2,468 &, 684 & $-36,876$ & $-33,893$ & $-51,700$ & 12 & 000 \\
\hline
\end{tabular}

Based on the output, the t-count was 51,700. The negative mark appeared before the $t$ count meant that the mean score before the treatment was lower than the mean score after the treatment. Thus, it was concluded that Crossword Puzzle did improved the scores of students' vocabulary mastery.

With the significance level of $5 \%$ and the degree of freedom (df) of 12 , the value of $t$ would be $(0,05 / 2=0,025)$. Therefore, the t-table would be 2,179 . The t-count $(51,700)$ was higher than the t-table $(2,179)$. Because of that, the null hypothesis $(\mathrm{HO})$ which was formulated as "There is no significant effect in students' vocabulary mastery before and after being taught by using crossword puzzle teaching strategy in SMA Amir Hamzah Medan" was rejected. Consequently, the alternative hypothesis $(\mathrm{Ha})$ which was formulated, as 
"There is significant effect in students' vocabulary mastery before and after being taught by using crossword puzzle teaching strategy at SMA Amir Hamzah Medan" was accepted.

The result of the T-test also showed that the significance value which was 0,00 was lower than the significance level which was 0,05 . It could be concluded that the null hypothesis ( $\mathrm{HO})$ which was formulated as "There is no significant effect in students" vocabulary mastery before and after being taught by using crossword puzzle teaching strategy in SMA Amir Hamzah Medan" was rejected. Sequentially, the alternative hypothesis (Ha) which was formulated as "There is significant effect in students' vocabulary mastery before and after being taught by using crossword puzzle teaching strategy at SMA Amir Hamzah Medan" was accepted.

The result of the data analysis of this research showed that the crossword teaching strategy gives a significant effect in students' vocabulary mastery at SMA Amir Hamzah Medan. The crossword teaching strategy improved the students' vocabulary mastery scores which was proven by the difference of the pre-test mean scores before being taught by crossword puzzle teaching strategy $(55,77)$ and the post-test mean scores after being taught by crossword puzzle teaching strategy $(91,15)$. The post-test mean score was higher than the pre- test mean score $(55,77<91,15)$. It was also proven by the t-test where the t-count of 51,700 was bigger than t-table of 2,179. It also showed that Ha was accepted and $\mathrm{HO}$ was rejected because the significance value which was 0,00 was lower than the significance level which was 0,05.

Based on the findings and discussion above, it is confirmed that crossword puzzle teaching strategy gives a positive effect towards students' vocabulary mastery by improving students' vocabulary scores. In addition, it is also confirmed that there is a significant effect in students' vocabulary mastery before and after having taught by using crossword puzzle teaching strategy in SMA Amir Hamzah Medan.

\section{Conclusion}

Based on the results of the data analysis, it is concluded that there is a significant effect in students' vocabulary mastery before and after being taught by using crossword puzzle teaching strategy in SMA Amir Hamzah Medan. Therefore, $\mathrm{Ha}$ is accepted while $\mathrm{HO}$ is rejected. It is also concluded that crossword puzzle teaching strategy gives a positive effect towards students' vocabulary mastery that could be seen on the difference between the pre- test's mean score which is considered poor $(55,77)$ and the post-test's mean score which is considered excellent $(91,15)$. Because crossword puzzle teaching strategy gives a significant effect towards students' vocabulary mastery, there are some suggestions that the researchers want to propose to the following people:

For English learners, in learning English especially vocabulary, crossword puzzle could be used to test and improve the vocabulary. So it is suggested to practice vocabulary using crossword puzzle by filling the crossword puzzle provided in the Internet or books.

For the school, since crossword puzzle teaching strategy is confirmed to be able to gives a positive significant effect towards students' vocabulary mastery, it is suggested for the school to be able to encourage teachers to apply crossword puzzle teaching strategy in teaching vocabulary.

For the teachers, especially English teachers, it is suggested that teachers could use crossword puzzle teaching strategy to improve students' vocabulary mastery. Any improvements are welcomed to make the learning process more exciting and fun. Besides crossword puzzle, teachers could also provide other games or teaching strategies which 
Effect of Crossword Puzzle Teaching Strategy towards Students' Vocabulary Mastery, Vivin Sunarko, Priska Novita Silalahi, Nani Haro, Sri Ninta Tarigan

could make the students motivated and excited to learn vocabulary without making them feel bored so students can feel that learning English becomes easier and more exciting.

Finally, for other researchers, this research is not perfect yet. Therefore, it is suggested that other researchers could conduct further research of crossword puzzle teaching strategy in a similar area by improving the approaches, the methods, or the procedures. However, this research can be used as a reference to conduct further researches in a similar area or in a different area of teaching.

\section{References}

Allen, V. F. (1983). Techniques in Teaching Vocabulary. Oxford University Press, 200 Madison Ave., New York, NY 10016

Hornby. 1987. Advance Learners Dictionary of English. England: Oxford University

Imam, F. (September 28, 2019). Pengaruh dan Sejarah Bahasa Inggris terhadap Perkembangan Indonesia. Kompasiana (online). Retrieved from https://www.kompasiana.com/imamfaisal2084/5bacc3a243322f37e017cb55/pengar uh-dan-sejarah-bahasa-inggris-terhadap-perkembangan-indonesia?page= all.

Karim, M., \& Hasbullah, F. A. (1986). Language Teaching Media. Jakarta: Karunia.

Prasetyo, B., \& Jannah, L. M. (2014). Metode Penelitian Kuantitatif, Jakarta: Raja Grafindo Perkasa.

Pratiwi, L. K. (2017). Using Contextual Crossword Puzzle to Improve the Vocabulary Mastery of Grade VIII C Students at SMP Negeri 7 Yogyakarta in the Academic Year of 2016/2017. English Language Teaching Journal, 6(4), 203-210.

Ratnawati, N., Bindarti, W. E., \& Rofiq, A. (2013). The Effect of Using Crossword Puzzle on Vocabulary Achievement of the Eighth Year Students at SMP Negeri 5 Jember. Pancaran Pendidikan, 2(2), 23-32.

Sugiyono, A. (2001). Metode Penelitian Pendidikan Pendekatan Kuantitatif. Kualitatif dan $R \& D$. Bandung: Penerbit Alfabeta.

Yudi Cahyono, B., \& Kusumaningrum, S. R. (2011). Practical Techniques for English Language Teaching. Malang: State University of Malang Press 